\title{
Study of the Physicochemical Quality of Irrigation Water in the Rural Commune of Tighassaline (Beni Mellal-Khenifra, Morocco)
}

\author{
NABYL BERRID ${ }^{1}$, LOUGRAIMZI HANANE ${ }^{2}$, OTMAN HAMIDI ${ }^{1}$, HOUDA EL-KHABBAZI ${ }^{3}$, \\ ZAKARIA ABIDLI ${ }^{3}$, RAHALI KELTOUM ${ }^{1}$, ADLAN HAMZA ${ }^{1}$, EL YEMLI AMINA ${ }^{1}$, EL \\ MAHJOUB AOUANE ${ }^{1}$ \\ ${ }^{1}$ Department of biology, University Ibn Tofail, Laboratory of Biotechnology, Quality and \\ Environment, Kenitra, MOROCCO. \\ ${ }^{2}$ Department of biology, University Ibn Tofail, Laboratory of Nutrition, Health and Environment, \\ Kenitra, MOROCCO. \\ ${ }^{3}$ Department of biology, University Ibn Tofail, Laboratory of Genetic and Biometric, Kenitra, \\ MOROCCO.
}

\begin{abstract}
Morocco considers itself among the countries that have made great efforts in the field of water savings. In agriculture, initiatives to switch from traditional irrigation to localized drip irrigation are widely encouraged. This method of water supply allows farmers to save water and nutrients while ensuring better yields in terms of quantity and quality. However, this production performance cannot be obtained without the obligatory passage to the analysis of all the factors of production. In this context, we evaluated during this study the physicochemical quality of two wells supplying the irrigation network of an apple tree farm in the rural commune of Tighassaline, Beni Mellal-Khenifra, Morocco.

The results showed that the $\mathrm{pH}$ values of the two wells are of the order of 7 and those recorded for the electrical conductivity are between $0.37 \mathrm{~ms} / \mathrm{cm}$ and $0.55 \mathrm{~ms} / \mathrm{cm}$. These results demonstrate the quality of the irrigation water, almost neutral and without any risk of salinity. These constants are supported by other measurements of anions and cations contained in the water samples taken. In this regard, the concentration of chloride and sulphate is practically low in the two wells, while the concentration of bicarbonate is twice as high in well 2 than in well 1. However, the most abundant cation compared to the others is sodium, with a concentration of the order of $1.10 \mathrm{meq} / \mathrm{l}$ and $0.9 \mathrm{meq} / \mathrm{l}$ for well 1 and well 2 respectively. The following study demonstrates the importance of these analyzes in the appreciation of one of the main production factors and it proves that the water from the two wells used to supply the irrigation network of the apple tree farm is very good quality.
\end{abstract}

Key-Words: - Physicochemical, Irrigation water, Apple tree, Well, Quality

Received: August 31, 2020. Revised: December 22, 2020. Accepted: December 24, 2020. Published: December 28, 2020

\section{Introduction}

All over the world, water is a vital element for the existence of humanity. This precious resource is directly involved in all human activities, which explains the strong pressure of its exploitation. Consequently, water resources are often subject to several constraints such as: temporal irregularity, pollution and high vulnerability to drought. In this regard, several scientists are raising awareness of the urgent need to adopt comprehensive strategies for the preservation of water resources and sounding the alarm on the scarcity of water and the possible territorial tensions that may be felt under the impact of climate change. Nonetheless, Moroccan efforts in water management can be qualified as considerable. The dams built ensure the storage and preservation of enormous quantities of water and the policy of generalization of drip irrigation systems in agriculture allows our country to better manage repetitive crises of drought and water shortage. Drip irrigation of plantations is part of sustainable agriculture, which aims to optimize water resources 
while ensuring an accurate supply of water and nutrients. This ferti-irrigation technique requires a high level of technical expertise and physicochemical analyzes of water resources in order to define the quality, chemical composition and usability of irrigation water supplies [1] Nevertheless, the incidence of groundwater pollution is higher in urban areas. The deterioration of the quality of water resources by the proliferation of different sources of pollution (fertilizers and pesticides, discharges of untreated wastewater, discharges of uncontrolled solid waste, mining, urbanization, etc.), it constitutes a threat as important as that linked to the quantitative imbalance [2] Water pollution not only affects the quality, but also threatens human health, economic development and social prosperity [3]

It is within this framework that this study was conducted, in order to assess the quality of irrigation water. The approach taken is to take water samples and further assess the physicochemical properties of the water from two wells supplying an apple tree farm water in the region of Beni Mellal-Khenifra, Morocco.

\section{Materials and methods}

\subsection{Presentation of the study area}

The Beni Mellal-Khenifra Region covers an area of $28,374 \mathrm{~km} 2$, or $4 \%$ of the territory of Morocco. Located in the center of the Kingdom, it was created following the new regional division of 2015. There are five provinces, namely: Azilal, Beni Mellal, Fquih Ben Salah, Khenifra and Khouribga; were brought together to create this new territorial entity [4]

The Region of Beni Mellal-Khenifra is known for the diversity of its reliefs. There are three distinct agro-ecological systems: Tadla Plain, Phosphate Plateau and the Middle Atlas Mountains. It is characterized by a continental climate: very hot in summer with a temperature exceeding $40{ }^{\circ} \mathrm{C}$, and cold in winter with a temperature of $0{ }^{\circ} \mathrm{C}$ [5] In general, average annual precipitation varies across agroecological systems and from place to place within the same system (Figure 1). The amount of precipitation varies according to the years and the reliefs of the region, from the northwest (phosphate plateau) to the southeast (mountains), its range can go from 100 to $700 \mathrm{~mm}$ [5] The region is drained by a main river, which is the Oued Oum Er-Rbia and its tributaries (Oued Derna, Oued El Abid, Oued Lakhdar and Oued Tassout). This wadi is mainly fed by the Middle Atlas where rainfall is important and where many sources bring a regular water level that the region experiences following precipitation and snowmelt.

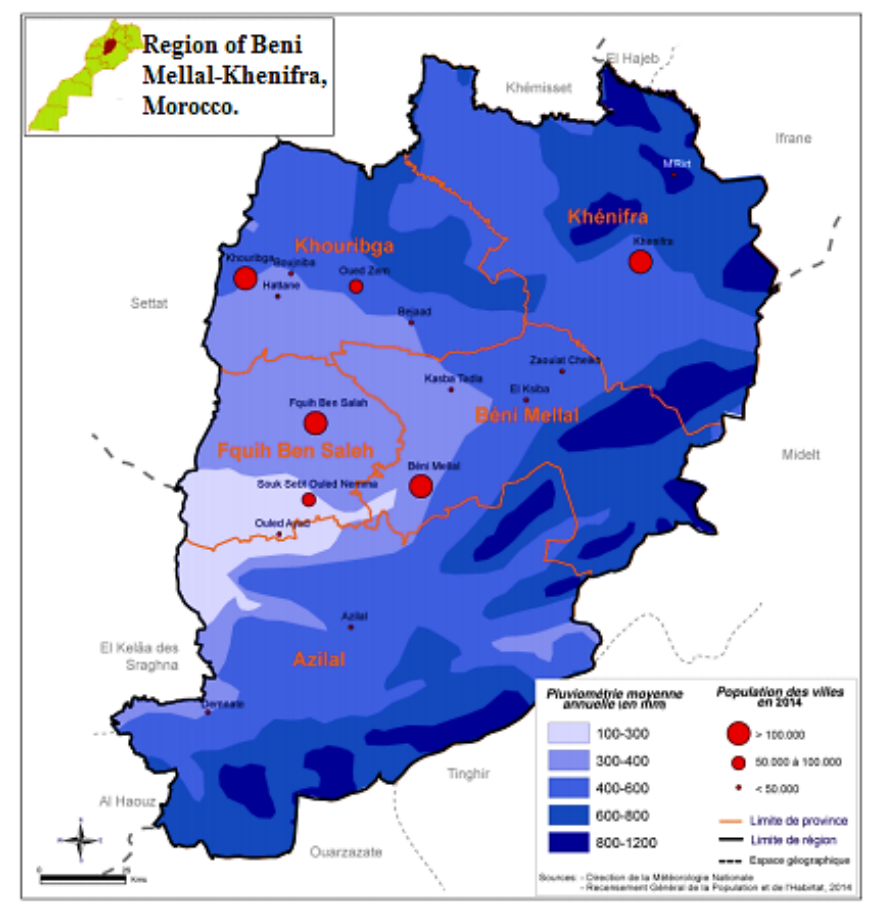

Figure 1. Annual distribution of precipitation in the region of Beni Mellal-Khenifra, Morocco [6]

\subsection{Study area}

The apple tree farm, object of the study, is located in the rural commune of Tighassaline, administratively belonging to the province of Khenifra, in the region of Beni Mellal-Khenifra, Morocco. Almost all the soils in this commune are calcimagnesic and their textures are generally silty with a slightly basic $\mathrm{pH}$.

\subsection{Irrigation water withdrawal}

Sampling was based on taking water samples from the two wells through which the apple tree farm was irrigated during cultivation. The water well samples taken on 12/25/2018 were placed in well-sealed plastic bottles, referenced by unique codes. Then transported in a cooler to the laboratory in order to measure the following elements: $\mathrm{pH}$, electrical conductivity (EC) and main elements: $\mathrm{HCO}_{3}{ }^{-} \mathrm{CO}_{3}{ }^{2-}$, $\mathrm{Cl}, \mathrm{Ca}^{++}, \mathrm{Mg}^{++}, \mathrm{K}^{+}, \mathrm{Na}^{+}$and $\mathrm{SO}_{4}{ }^{2-}$.

\subsubsection{Definition and procedure of $\mathrm{pH} / \mathrm{EC}$ measurement}

The $\mathrm{pH}$ is a unit of measurement for the acidity of water on a scale of 0 to 14 . It is determined using a $\mathrm{pH}$ meter. The electrical conductivity (EC) allowed a quick but very approximate assessment of the total mineralization of the water. Electrical conductivity is measured using a conductivity meter. In order to 
determine the concentration of soluble salts in water, the following relationship is applied:

EC $(\mathrm{mmhos} / \mathrm{cm})=$ reading $(\mathrm{ms} / \mathrm{cm}) * 1.105$

EC $(\mathrm{mmhos} / \mathrm{cm}) * 0.64=$ the concentration of water-soluble salts $(\mathrm{g} / \mathrm{L})$.

\subsubsection{Ionic balance of water}

The chemical analysis of the water is done by volumetric determination for (chloride, bicarbonate, carbonate, calcium and magnesium) and by flame spectrophotometry for (sodium, potassium and sulphate). The assay methods described below come from the work of Rodier [7]

\section{Chlorides}

The $\mathrm{Cl}^{-}$ions are assayed with a standard solution of silver nitrate (AgNO3; 0.02N) in the presence of potassium chromate (K2CrO4). Chloride will precipitate as silver chloride (AgCl).

The calculation is done according to the following formula:

$$
\left.(\mathrm{mg} / \mathrm{L})=\underset{\text { Vsample }(3)}{\left(\mathrm{V}\left(\mathrm{AgNO}_{3}\right) \times 0.02\right.} \times 35.45\right) * 1000 /
$$

$A=$ volume of titrant used, $N$ is normality of silver nitrate and Vsample is volume of sample used $(\mathrm{mL})$.

\section{Magnesium}

The contents of Mg2+ ions are calculated by the difference between total hardness and calcium expressed in meq/l, according to the following formula:

$$
\begin{gathered}
\operatorname{meq}\left(\mathrm{Mg}^{2+} / \mathrm{l}\right)=((\mathrm{N}-\mathrm{n}) * 0,02 / 10) * 1000=2(\mathrm{~N}-\mathrm{n}) \\
\operatorname{mg}\left(\mathrm{Mg}^{2+} / \mathrm{l}\right)=2(\mathrm{~N}-\mathrm{n}) * 24
\end{gathered}
$$

$N(\mathrm{~mL})$ the volume of EDTA $(0.02 \mathrm{~N})$ poured.

\section{Bicarbonates}

Natural waters have a neutral $\mathrm{pH}$, which corresponds to the stability range of $\mathrm{HCO}^{3-}$ ions, $\mathrm{CO}_{3}{ }^{2-}$ ions are absent. The $\mathrm{HCO}^{3-}$ ions are dosed by acidimetry using a $0.02 \mathrm{~N} \mathrm{H}_{2} \mathrm{SO}^{4}$ sulphuric acid solution. The coloured indicator used is Bromocresolgreen which gives a blue color.

The calculation of this parameter is done according to the following formula:

$$
\begin{gathered}
\operatorname{meq}\left(\mathrm{HCO}_{3}{ }^{-}\right) / \mathrm{L}=\mathrm{N}(\mathrm{mL}) * 0,02 * 1000 * 0,1=\mathrm{N} \\
(\mathrm{mL}) * 2 * 61(\mathrm{mg} / \mathrm{L})
\end{gathered}
$$

$n(m L)$ volume of sulfuric acid poured into the carbonate dosage, and $N(\mathrm{~mL})$ the volume of sulfuric acid poured into the bicarbonate dosage.

\section{Calcium}

It is dosed by complexometry in an alkaline environment at $\mathrm{pH}=10$ in the presence of sodium hydroxide $(\mathrm{NaOH})$. We titrate with ethylenediamine tetra-acetic acid (E.D.T.A.), with murexide as a coloured indicator.

The calculation formula is as follows:

$$
\begin{aligned}
& \operatorname{meq}(\mathrm{Ca} 2+/ \mathrm{L})=\mathbf{n}(\mathrm{mL}) * 0,02 * 0,1 * 1000=2 n \\
& \operatorname{Mg}(\mathrm{Ca} 2+/ \mathrm{L})=2 \mathrm{n} * 20
\end{aligned}
$$

$n(m L)$ the volume of EDTA added $(0.02 N)$

\section{Sodium and Potassium}

The dosage of these two ions is based on the method of flame spectrophotometry. Its principle is based on the dissociation of atoms during their passage through the flame, and which emit energy upon excitation. Each element will emit a specific wavelength that will be detected by optical filters of each element. The principle consists in making a calibration curve of the element to be dosed with known concentrations, then evaporating in the flame of the photometer the water to be analyzed and determining the content of $\mathrm{Na}^{+}$or $\mathrm{K}^{+}$knowing the absorption wavelength of each of them.

The calculation formula is as follows:

$$
\begin{gathered}
\mathrm{mg} \mathrm{Na}^{+} / \text {litre }=\text { meq } \mathrm{Na}^{+} / \text {litre } * 23 \\
\mathrm{mg} \mathrm{K}^{+} / \text {litre }=\text { meq K} \\
\hline
\end{gathered}
$$

In also calculates the sodium absorption rate which is expressed by the SAR (Sodium Absorption Ratio) and is calculated according to the following formula:

$$
\mathrm{SAR}=\mathrm{Na}^{+} /\left[\left(\mathrm{Ca}^{++}+\mathrm{Mg}^{++}\right) / 2\right]^{1 / 2}
$$

\section{Sulphates}

They are analyzed using stabilized barium chloride $\left(\mathrm{BaCl}_{2}\right)$, we stirred 2-3 times, and then after 15 seconds we stirred again and read with a spectrophotometer at $650 \mathrm{~nm}$.

For the calculation formula:

$$
\begin{gathered}
\mathrm{meq} \mathrm{SO}_{4} / \text { litre }=((\mathrm{t}+\mathrm{N})-\mathrm{v}) * 2 \\
\left.\mathrm{mg} \mathrm{SO}_{4} / \text { litre }=2 *(\mathrm{t}+\mathrm{N})-\mathrm{v}\right) * 48
\end{gathered}
$$


$\mathrm{N} \mathrm{ml}$ of complexon III N/50 used for complexing $\left(\mathrm{Ca}^{++}\right.$ $\mathrm{Mg}$ ). $\mathrm{V} \mathrm{ml}$ used to complex $\mathrm{Ca}^{++} \mathrm{Mg}^{++} \mathrm{Ba}$ in excess + $\mathrm{Mg}^{++}$added. $\mathrm{T} \mathrm{ml}$ used to complex Ba and $\mathrm{Mg}^{++}$.

\section{Results and discussion}

\section{$3.1 \mathrm{pH}$}

The $\mathrm{pH}$ (hydrogen potential) measures the activity of $\mathrm{H} 3 \mathrm{O}+$ ions in water. It thus reflects the balance between acids. The $\mathrm{pH}$ values measured for the samples taken from the two wells are approximately 7 (Table 1). This recorded $\mathrm{pH}$ value confirms the excellent quality of the irrigation water from the two wells studied. A neutral $\mathrm{pH}$ means that the quantities of $\mathrm{H}^{+}$and $\mathrm{OH}^{-}$ions presented in the water are at equal levels and subsequently the quantities of water supplied by irrigation rotation in the different irrigation sectors of the apple trees are beneficial to trees and do not lead to salinity or toxicity problems. The apple tree adapts to a wide range of soils. However, well-drained, slightly acidic (pH 6.5 to 6.7), clay loamy, deep soils rich in organic matter are most favorable for apple growing [8] Heavy clay soils with high water holding capacity should be avoided as much as soils with high active limestone content [9] The $\mathrm{pH}$ conditions a large number of physicochemical balances and depends on multiple factors including temperature and origin of water. Similar results were obtained by El yemli et al. through an analysis carried out on eight water points distributed in the region of Sidi Taibi, Kénitra, They recorded $\mathrm{pH}$ values ranging from 7 to 7.5 .

Table 1. $\mathrm{pH}$ and electrical conductivity analysis of the two wells.

\begin{tabular}{|c|c|c|c|c|}
\hline \multirow{2}{*}{$\begin{array}{c}\text { Nature } \\
\text { of } \\
\text { water }\end{array}$} & $\begin{array}{c}\mathbf{N}^{\circ} \\
\text { Sample }\end{array}$ & $\begin{array}{c}\text { Sampling } \\
\text { date }\end{array}$ & $\mathbf{p H}$ & $\mathbf{E C}$ \\
\hline Well 1 & Lot P1 & $25 / 12 / 2018$ & 7.00 & $\mathbf{m s} / \mathbf{c m}$ \\
\hline Well.2 & Lot P2 & $25 / 12 / 2018$ & 6.90 & 0.55 \\
\hline
\end{tabular}

Regarding the second parameter measured, the electrical conductivity reading of this parameter reflecting the overall degree of mineralization of the water from the two wells. The values obtained are between $0.37 \mathrm{~ms} / \mathrm{cm}$ and $0.55 \mathrm{~ms} / \mathrm{cm}$ and they are less than $0.75 \mathrm{mmhos} / \mathrm{cm}$ which they clearly show that the irrigation water of the two wells is very good quality (Table 2).
Table 2. Risk of salinity in irrigation water as a function of electrical conductivity [11]

\begin{tabular}{|c|c|c|}
\hline Risk & $\begin{array}{c}\text { Total } \\
\text { dissolved } \\
\text { (mg/L) }\end{array}$ & mmhos/cm \\
\hline Nil & $<500$ & $<0.75$ \\
\hline Light & $500-1000$ & $0.75-1.5$ \\
\hline Moderate & $1000-2000$ & $1.5-3.00$ \\
\hline Severe & $>2000$ & $>3.0$ \\
\hline
\end{tabular}

According to the standard of the Ministry of Energy, Mines, Water and the Environment, the irrigation water of the supply wells they are qualified as excellent for all types of vegetable production and in particular for growing apple trees. As for the risk of salinity, it is qualified as zero, according to the same standard. The same assessment of the risk of salinity based on electrical conductivity has been defined by FAO according to table 3 and confirms that the irrigation water of these two wells is not saline and has no restrictions for the irrigation. A study by El Khodrani et al showed that groundwater belonging to the commune of Sfafaa, Sidi Slimane, Morocco (more than $70.6 \%$ of the water) has a higher potential for soil salinization and it can lead to a significant reduction in yields, especially for sensitive crops.

Table 3. Scale of appreciation of salinity of water for irrigation [13]

\begin{tabular}{|l|l|l|l|}
\hline Salinity & $\begin{array}{l}\text { No } \\
\text { restrictions } \\
\text { for } \\
\text { irrigation }\end{array}$ & $\begin{array}{l}\text { Moderate } \\
\text { Restriction }\end{array}$ & $\begin{array}{l}\text { High } \\
\text { restriction } \\
\text { for } \\
\text { irrigation }\end{array}$ \\
\hline $\begin{array}{l}\text { Conductivity } \\
\text { in } \\
\mathrm{mmhos} / \mathrm{cm}\end{array}$ & $<0.75$ & $0.75-3.0$ & $>3.0$ \\
\hline
\end{tabular}

\subsection{Main components}

\subsubsection{Anions}

The results of the elements analyzed showed that the two wells studied differed significantly in terms of sulphate and bicarbonate content; which is twice as concentrated in well 2 as in well 1. (Figure 2). 
While these two wells record the same, chloride values which are of the order of $1.50 \mathrm{meq} / \mathrm{l}$. A similar study reported by Nouayti et al. analyzes the physicochemical quality of the waters of the Jurassic aquifers of the Upper Ziz basin. The waters of the downstream part of the basin are characterized by high values of electrical conductivity and chlorides associated with evaporitic sediments. Chlorides They are often used as an index of pollution [15] In addition, the comparison of the elements analyzed against the standard of guidelines for the interpretation of the quality of irrigation water presented in table 4 shows the low concentration of these elements except for bicarbonate at well level 1 .

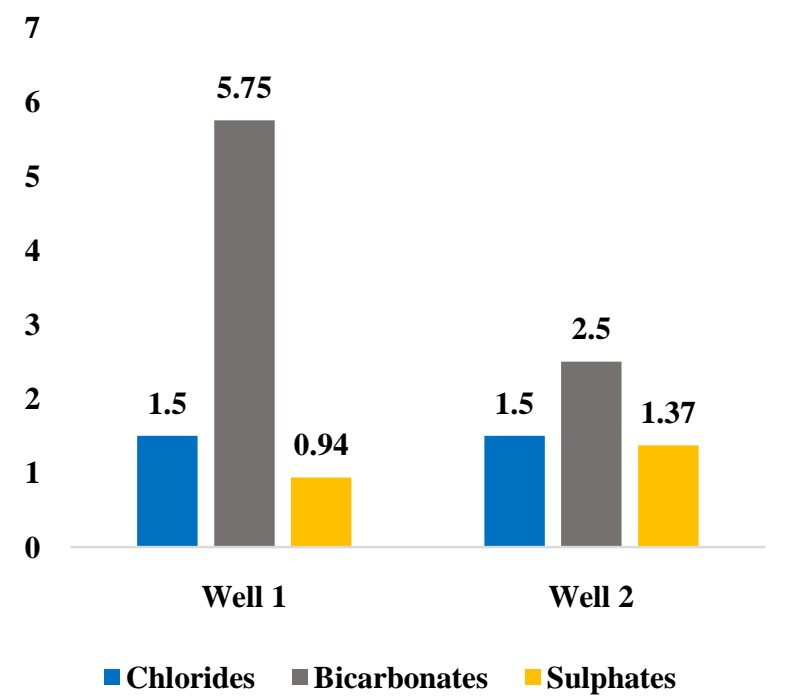

Figure 2. Anion concentrations in well water in meq/l.

Table 4. Anion concentration ranges in meq/l [16]

\begin{tabular}{|l|c|c|c|}
\hline Elements & Low & Medium & High \\
\hline Chlorides & 2.5 & 5.61 & 8 \\
\hline Bicarbonates & 2.4 & 4.6 & 6.6 \\
\hline Sulphates & 3 & 4.51 & 6.1 \\
\hline
\end{tabular}

Table 5 shows the statistical analysis of the chlorides, bicarbonates and sulphates content in the two wells. The coefficient of variation is an indicator of dispersion presented as a percentage. According to the results of the anion analyzes obtained, the coefficient of variance of bicarbonates is the highest, which shows a wide dispersion around the mean. The content of bicarbonates in groundwater depends mainly on the presence of carbonate minerals in the soil and aquifer, as well as the $\mathrm{CO}^{2}$ content of the air and soil in the catchment area [17]

Table.5 Aggregate anion content statistics.

\begin{tabular}{|l|l|l|l|l|l|l|}
\hline & \multicolumn{2}{|c|}{ Chlorides } & \multicolumn{2}{c|}{ Bicarbonates } & \multicolumn{2}{c|}{ Sulphates } \\
\cline { 2 - 7 } & Well.1 & Well.2 & Well.1 & Well.2 & Well.1 & Well..2 \\
\hline Average & 27.38 & 27.38 & 178.25 & 77.50 & 22.47 & 33.46 \\
\hline $\begin{array}{l}\text { Standard } \\
\text { deviation }\end{array}$ & 36.59 & 36.59 & 243.95 & 106.07 & 30.45 & 45.38 \\
\hline CV (\%) & 133.67 & 133.67 & 136.86 & 136.86 & 135.51 & 135.63 \\
\hline
\end{tabular}

\subsubsection{Cations}

The cation concentrations are presented in figure 6 . The most abundant cation compared to the others is sodium, with a concentration of the order of 1.10 $\mathrm{meq} / \mathrm{l}$ for the first well and of $0.9 \mathrm{meq} / \mathrm{l}$. for the second well, followed by potassium with concentrations of $1.06 \mathrm{meq} / \mathrm{l}$ and $0.23 \mathrm{meq} / \mathrm{l}$ respectively for the two wells (Figure 3 ). A study carried out in the Skhirat region showed that sodium and calcium are the predominant cations while chloride and sulphate are the predominant anions [18]

Exchangeable sodium has a significant impact on the physical and chemical properties of soils. As the exchangeable water content increases, the soil tends to disperse, becomes less permeable to water and is no longer suitable for cultivation practices [19] Irrigation water stagnates on the surface of the soil and no longer reaches the roots. However, the amount of water needed by the apple tree for its growth and production varies from 700 to 900 $\mathrm{mm} /$ year [8] The water requirement of the apple tree during the growing season (March to September) would be $600 \mathrm{~mm}$ [20] Therefore, it is necessary to maintain adequate infiltration conditions in irrigated soils and in particular, to prevent the soil exchange complexes from becoming loaded with $\mathrm{Na}^{+}$. Abnormally high sodium levels may result from 
leaching of salts, or percolation through salty soils or the infiltration of brackish water [21, 22]

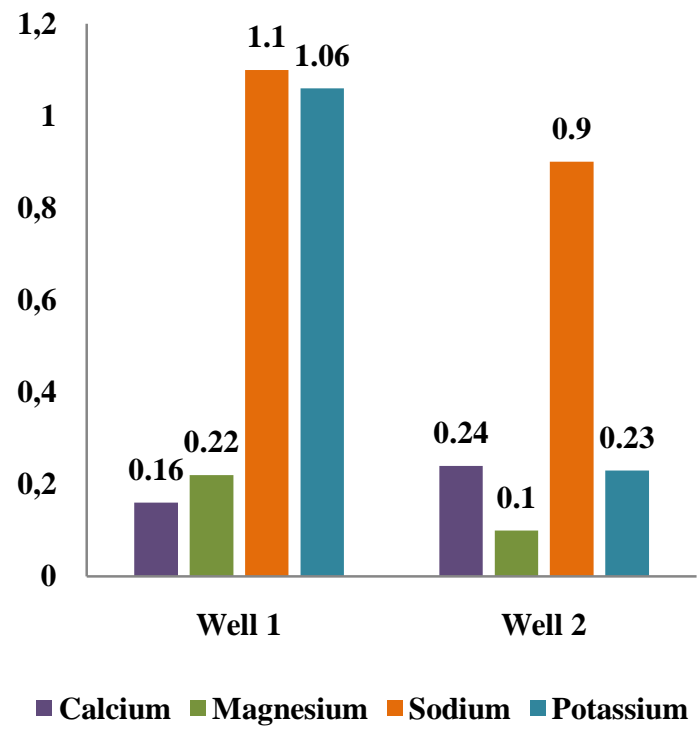

Figure 3. Cation concentrations in well water in meq/l.

The sodium risk of irrigation water is expressed by the SAR (Sodium Absorption Ratio) used to assess the possible degradation of the soil structure and the alteration of its physical qualities. According to the SAR results, the proportion of sodium adsorbed is 2.58 for well 1 and 2.18 for well 2, indicating a very low contribution of sodium to soil permeability according to the SAR classification (Table 6).

Table 6. Rankings according to SAR [23]

\begin{tabular}{|c|c|}
\hline SAR & Risk \\
\hline$<10$ & Low \\
\hline $10<$ SAR $<18$ & Medium \\
\hline $10<$ SAR $<18$ & High \\
\hline$>26$ & Very high \\
\hline
\end{tabular}

The magnesium concentrations are generally too low to compare to the standards of the guidelines for the interpretation of irrigation water quality presented in Table 7. They recorded values of 0.22 meq/l and $0.10 \mathrm{meq} / \mathrm{l}$ for well 1 and well 2 respectively. Nevertheless, the coefficient of variance for the cation shown in table 8 revealed that magnesium represents the lowest coefficient, which shows a lower mean dispersion, unlike potassium, which has a higher coefficient of variance.

Table 7. Cation concentration ranges in meq/l [16]

\begin{tabular}{|c|c|c|c|}
\hline & Low & Medium & High \\
\hline Calcium & 0.6 & 1.51 & 2.6 \\
\hline Magnesium & 0.3 & 0.77 & 2 \\
\hline Potassium & 0.17 & 0.26 & 0.39 \\
\hline Sodium & 0.13 & 0.18 & 0.26 \\
\hline
\end{tabular}

Table 8: Aggregate anions content statistics.

\begin{tabular}{|c|c|c|c|c|}
\hline \multirow{2}{*}{} & \multicolumn{2}{|c|}{ Calcium } & \multicolumn{2}{c|}{ Magnesium } \\
\cline { 2 - 5 } & Well 1 & $\begin{array}{c}\text { Well } \\
\text { water.2 }\end{array}$ & $\begin{array}{c}\text { Well } \\
\text { water.1 }\end{array}$ & $\begin{array}{c}\text { Well } \\
\text { water.2 }\end{array}$ \\
\hline Average & 1.68 & 2.12 & 1.43 & 0.65 \\
\hline $\begin{array}{c}\text { Standard } \\
\text { deviation }\end{array}$ & 2.15 & 2.66 & 1.71 & 0.78 \\
\hline CV (\%) & 127.95 & 125.41 & 119.66 & 119.66 \\
\hline & Sodium & Potassium \\
\cline { 2 - 5 } & $\begin{array}{c}\text { Well } \\
\text { water.1 }\end{array}$ & $\begin{array}{c}\text { Well } \\
\text { water.2 }\end{array}$ & $\begin{array}{c}\text { Well } \\
\text { water.1 }\end{array}$ & $\begin{array}{c}\text { Well } \\
\text { water.2 }\end{array}$ \\
\hline \multirow{2}{*}{ Average } & 13.20 & 10.80 & 21.25 & 4.53 \\
\hline \multirow{2}{*}{$\begin{array}{c}\text { Standard } \\
\text { deviation }\end{array}$} & 17.11 & 14.00 & 28.55 & 6.08 \\
\hline \multirow{2}{*}{ CV (\%) } & 129.64 & 129.64 & 134.37 & 134.24 \\
\hline
\end{tabular}

The analysis of all these elements allows local managers to have a clear and precise idea of the physicochemical characteristics of irrigation water and to deduce the frequency and dosage of the quantities of water supplied. Likewise, these analyzes facilitate decision making on possible combinations of nutrients.

\section{Conclusion}

Low slopes, low permeability and evaporation impede and slow down the natural drainage of the surface and subsoil. These factors thus disturb the free circulation of water and affect its qualities. The 
salinity of the water is a direct consequence of this natural alteration and irrigation with saline water can lead to difficult situations. The results obtained in this study, which focuses on the physicochemical analysis of the irrigation water. They prove that the water from the two wells used to supply the irrigation network of the apple tree farm is of very good quality. These waters are almost neutral; they have a balanced chemical composition and generally do not contain any chemical element that could interfere with the proper development of crops. In terms of recommendations, we strongly encourage farmers to consider all analyzes and mainly physicochemical analyzes of water as a starting point for any plant production system in order to project on the possible combinations and interactions of the triangle of water, soil, plant production with the main agricultural inputs.

\section{References:}

[1] Mahhou, A. Fertilization of fruit-bearing rosaceae. Monthly Bulletin of Information and Liaison of the National Agriculture Technology Transfer Program. 2008. 165. P 4.

[2] Nouayti, N., Khattach, D. \& Hilali, M. Assessment of the physicochemical quality of groundwater from Jurassic aquifers in the upper Ziz basin. Journal of Materials and Environmental Science. 2015. 6 (4), 1068-1081.

[3] Milovanovic, M. Water quality assessment and determination of pollution sources along the Axios/Vardar River, Southeastern Europe. 2007. Desalination 213:159-173

[4] Ministry of Transport and Logistics Equipment andWater,2015.http://www.equipement.gov.ma/ CarteRegion/RegionBeniMellal/Presentationde-la region/Monographie/Pages/Monographiede-la-region.aspx

[5] High Commission for Planning, 2017. Beni Mellal-Khenifra Regional Monograph https://www.hcp.ma/regiondrta/docs/Publication s/Monographie\%20R\%20gionale\%20BMK\%20 2017.pdf.

[6] National Portal of Territorial Collectivities, 2015. The region of beni mellal khenifra. General monograph.http://www.pncl.gov.ma/fr/LesColle ctivit\%C3\%A9sterritoriales/Documents/MONO GRAPHIE\%20DE\%20LA\%20REGION\%20DE \%20\%20BENI\%20MELLAL\%20KHNIFRA\% 20FR.pdf.

[7] Rodier, J. Water analysis (natural water, waste water, sea water), 7th ed. 1984.p. 177. Dunod Edition, Paris, France.
[8] Walali, .L. D. E., Skiredj, H. Technical sheet. Apricot, plum, pear and apple. Technology transfer in agriculture. 2013. Hassan II Agronomic and Veterinary Institute, Rabat, Morocco.

https://www.agrimaroc.net/2018/05/23/lepommier/

[9] Agricultural credit in Morocco. Accessed on November 17, 2020. Available at:https://www.fellah-trade.com/fr/ plant-sector / technical-sheets / apple tree.

[10] El Yemli, A., Berrid, N., Youssef, A., Idrissi, Ali k., Hussein , Fuad Al-Nahmi , Ghazi, A. Study of the physico-chemical quality of the Groundwater in the SidiTaibi, Kenitra, Morocco, Egyptian Journal of Aquatic Biology \& Fisheries. 2020. 24(3), 109 - 124.

[11] Aquatech, 2017. Water purification and treatment.http://www.lenntech.fr/applications/irr igation/salinite/irrigation/salinite-risqueirrigation.htm

[12] Ministry of Energy, Mines, Water and the Environment.http://www.environnement.gov.m $\mathrm{a} / \mathrm{fr} / \mathrm{eau} /$

[13] FAO. Capacity Building Project on the Safe Use of Wastewater in Agriculture. National Report of Morocco. United Nations Food and Agriculture Organization, UN-Water, United Nations University Institute for Water, Environment and Health. 2011.

[14] El Khodrani, N., Zouahri, A., Arfaoui, A., Iaaich, H., El Oumlouki, K., Yahyaoui, A., \& Fekhaoui, M. Study of physicochemical quality of groundwater in the rural commune of SFAFAA (Sidi Slimane Gharb, Morocco). J Mater Environ Sci [Internet] 2016. 7(8), 285260.

[15] Abdoulaye D. N., Khadijettou M. M. S., El Kory, M. B., Ould Sid'M., Ould Kankou, A., Baudu., M. Contribution to the study of the spatial and temporal evolution of the physicochemical quality of water from the right bank of the Senegal river, J. Mater. About. Sci. 5 (1). 2014. 320-329.

[16] Ayers, R.S., D.S., Westcot. Water quality for agriculture. Irrigation and Drainage. 1985. Paper 29. FAO, Rome.

[17] Matthess, G. Geol. Mijinbouw, 53, 194. Forstner U ETWittmann GTW Metal pollution in the Aquatic Environment. 1994. 355-359.

[18] Zouahri, A., Dakak, H., Douaik, A., El Khadir, M., \& Moussadek, R. Evaluation of groundwater suitability for irrigation in the Skhirat region, Northwest of Morocco. 
Environmental monitoring and assessment. 2015.187(1), 4184.

[19]Colmet-Daage, F., Gautheyrou, J., Gautheyrou, M., Kimpe, C. D. \& Fusil, G. Dispersion and study of fine fractions of allophane soils in the West Indies and Latin America: part 1. The dispersion. Orstom notebooks. Pedology Series. 1972. 10 (2), 169-191.

[20] Oukabli, A. The apple tree: a local culture in high altitude areas. Monthly Bulletin of Information and Liaison of the National Agriculture Technology Transfer Program. 2004. 115 (4).

[21] Bermond R. and Perrdon C. Parameters of water quality. Ministry of the Environment Paris, 1979. 259.

[22] Rodier, J., Legube, B., \& Merlet, N. The Water Analysis 9th edition. Fully updated, Dunod. 2009. Paris. France.

[23] Ouali, N. \& Taiebi, O. H. Assessment of the physico-chemical quality of irrigation water in the MAGRA region (wilaya of M'sila) (Doctoral dissertation, Mohamed BOUDIAF University of M'Sila). 2019.

\section{Contribution of individual authors to the creation of a scientific article (ghostwriting policy)}

Nabyl Berrid, defined the methodology, analyzed and writing (original draft) the paper.

Lougraimzi Hanane, gathered the data and participated writing the paper and critical revision of the manuscript.

Otman Hamidi translate the article into English.

Houda El-khabbazi, Zakaria Abidli were responsible for the Statistics.

Rahali Keltoum, participated in the implementation of fieldwork.

Adlan Hamza designed the methods used for the conduction of the study.

El yemli Amina was responsible for supervising references.

El mahjoub Aouane was responsible for proofreading and editing the work. 